\title{
Effects of Sertraline on Sperm Motility, Number and Viability and Its Relation to Blood Levels of Testosterone, FSH and LH in Adult Male Mice
}

\author{
Mahsa Hadipour Jahromy ${ }^{*}$, Anousheh Amini Moghadam² \\ ${ }^{1}$ Department of Pharmacology, Tehran Medical Sciences Branch, Islamic Azad University, Tehran, Iran \\ ${ }^{2}$ Department of Biology, North Branch, Islamic Azad University, Tehran, Iran \\ Email: ${ }^{*}$ jahromymh@yahoo.com
}

Received 9 February 2014; revised 9 March 2014; accepted 17 March 2014

Copyright (C) 2014 by authors and Scientific Research Publishing Inc.

This work is licensed under the Creative Commons Attribution International License (CC BY).

http://creativecommons.org/licenses/by/4.0/

(c) (†) Open Access

\begin{abstract}
Abstrasct
The aim of this study was to investigate the effects of Sertraline on gonad-pituitary cycle (Testosterone, FSH and $\mathrm{LH}$ ) and reproductive cells in adult male Balb/C mice. Adult male Balb/C mice were divided into the following 5 groups: control group with no treatment, sham group which received solvent, and the experimental groups which received one dose of Sertraline $(0.0178 \mathrm{mg} / \mathrm{kg})$ in the first group, two doses of Sertraline $(0.0356 \mathrm{mg} / \mathrm{kg})$ in the second group, and three doses of Sertraline $(0.0534 \mathrm{mg} / \mathrm{kg})$ in the third group. Mice were anaesthetized after 7 weeks. Serum samples were collected and Testosterone, FSH and LH levels of serum were assayed. Vase deferans were analyzed for motility, number and viability of sperms. The results of this study showed that the viability, count and motility of sperms were decreased. Testosterone level of blood was also decreased while FSH was increased. There was no significant change in LH level. It is suggested that Sertraline at higher dose decreases sperm production and has the potential to affect adversely fertility in male mice.
\end{abstract}

\section{Keywords}

Sertraline, Sperm, Testosterone, FSH, LH

\section{Introduction}

Sertraline, a member of the class of the selective serotonin reuptake inhibitors (SSRIs), is a compound primarily

*Corresponding author.

How to cite this paper: Jahromy, M.H. and Moghadam, A.A. (2014) Effects of Sertraline on Sperm Motility, Number and Viability and Its Relation to Blood Levels of Testosterone, FSH and LH in Adult Male Mice. Advances in Sexual Medicine, 4, 17-24. http://dx.doi.org/10.4236/asm.2014.42004 
used as an antidepressant drug, but it is also applied in the correction of other psychic deviations like obsessive compulsive disorder (OCD), premenstrual dysphoric disorder (PMDD), posttraumatic stress disorders (PTSD) [1]. Treatment strategy is strongly influenced by factors such as type of depression, patients' previous response to treatment, drug-related mood instability, drug interactions, safety and tolerability profile, compliance, latency in overdose, combined psychiatric disorders [2].

The selective serotonin reuptake inhibitors (SSRIs) enhance serotonergic transmission through relatively selective inhibitions of its neuronal reuptake. They are safe in overdose than tricyclic antidepressants (TCAs) and have fewer autonomic side effects. Besides all these beneficial effects, there are some reports indicating that sertraline may have some side effects on reproductive system [3] [4].

Spermatogenesis is the process of germ cell proliferation and differentiation within the seminiferous tubules of the testes leading to haploid, free spermatozoon [5] [6]. In response to GnRH from the hypothalamus, the gonadotropins LH and FSH are produced and released from the anterior pituitary and stimulate Testosterone release from Leydig cells and Sertoli cells [7]-[9].

Besides, seminiferous epithelium is capable of producing esterogenes from testosterone to regulate spermatogenesis [10] [11].

The fact that apoptosis is suppressed by testosterone indicates that testosterone in human male is a critical germ cell survival factor [12].

In the present study, we investigated the effects of sertraline, on motility, number and viability of sperm and its relation to Testosterone, FSH and LH levels of blood in adult male Balb/C mice.

\section{Materials and Methods}

Adult male Balb/C mice were randomly divided into five groups of seven animals: three experimental groups, one control and one sham group. Each group was kept in separate cages. Animals were maintained at temperature of $23^{\circ} \mathrm{C} \pm 2^{\circ} \mathrm{C}$, and diurnal light-dark cycle (12-h light: 12-h darkness) with free access to food and water. The experimental groups received one, two, and three doses of sertraline $(0.0178 \mathrm{mg} / \mathrm{kg}, 0.0356 \mathrm{mg} / \mathrm{kg}$, and $0.0534 \mathrm{mg} / \mathrm{kg}$ ) regarding the amount administers in human. Control and sham groups received nothing and distillated water, respectively. All treatments were made orally using feeding needle.

After seven weeks all the mice were anaesthetized with chloroform, the vase deferans separated and blood samples were collected. Neubauer lams were used to observe motion and to count sperms, and eosin-negrosine dyeing to study their viability. Observations were made via optical microscope.

After centrifugation, serum samples were seperated, frozen and stored at $-20^{\circ} \mathrm{C}$ until assayed. Concentrations of testosterone, FSH, and LH in the serum were determined by radio immune assay (RIA), using kits from Padtan Elm kit.

\section{Statistical Analysis}

All data were expressed as $\bar{X} \pm$ S.E.M . Statistically, significant differences between groups were determined by analysis of variance (One-way ANOVA), followed by Tukey test. $\mathrm{P} \leq 0.05$ and $\mathrm{P} \leq 0.001$ were considered as significant.

\section{Results}

The results indicate a significant decrease in motility, number and viability of sperm after seven week sertraline administration, in a dose-dependent manner. There was a significant decrease in testosterone level of blood. Using three doses of sertraline $(0.0534 \mathrm{mg} / \mathrm{kg})$, it has the most influence on decreasing the testosterone level of blood. On the other hand, there was a significant increase in FSH level of blood while using three doses of sertraline with the most influence on FSH level of blood. There were no significant changes on LH level of blood.

\subsection{Sperm Motility, Number and Viability}

The results of mean sperm motility, number and viability are presented in Figures 1-3, respectively.

a) Effects of sertraline on sperm motility: There is a significant decrease in motility of sperm. Three doses of sertraline $(0.0534 \mathrm{mg} / \mathrm{kg})$ per day have the most significant effect on decreasing the motility of sperm (Figure 1).

b) Effects of sertraline on sperm count: Significant decrement in sperm count observed dose-dependently 


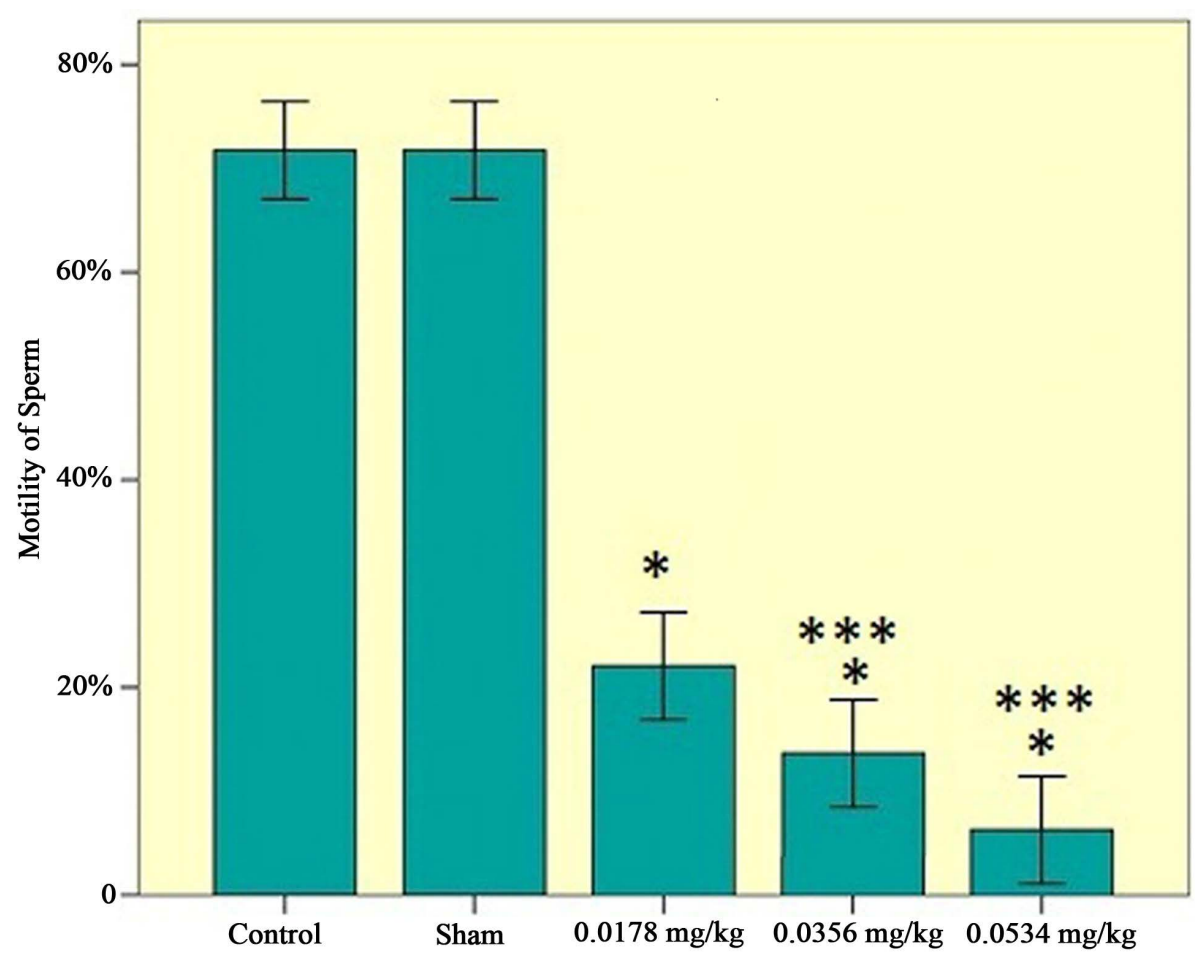

Figure 1. Motility of sperm among the experimental groups $(0.0178 \mathrm{mg} / \mathrm{kg}, 0.0356 \mathrm{mg} / \mathrm{kg}$, $0.0534 \mathrm{mg} / \mathrm{kg}$ ), control and sham groups. Statistical analysis (Tukey test) was performed on the $\bar{X} \pm$ S.E.M of the absolute values, ${ }^{*} \mathrm{P} \leq 0.05$ and ${ }^{* * *} \mathrm{P} \leq 0.001$ for experimental, control and sham groups.

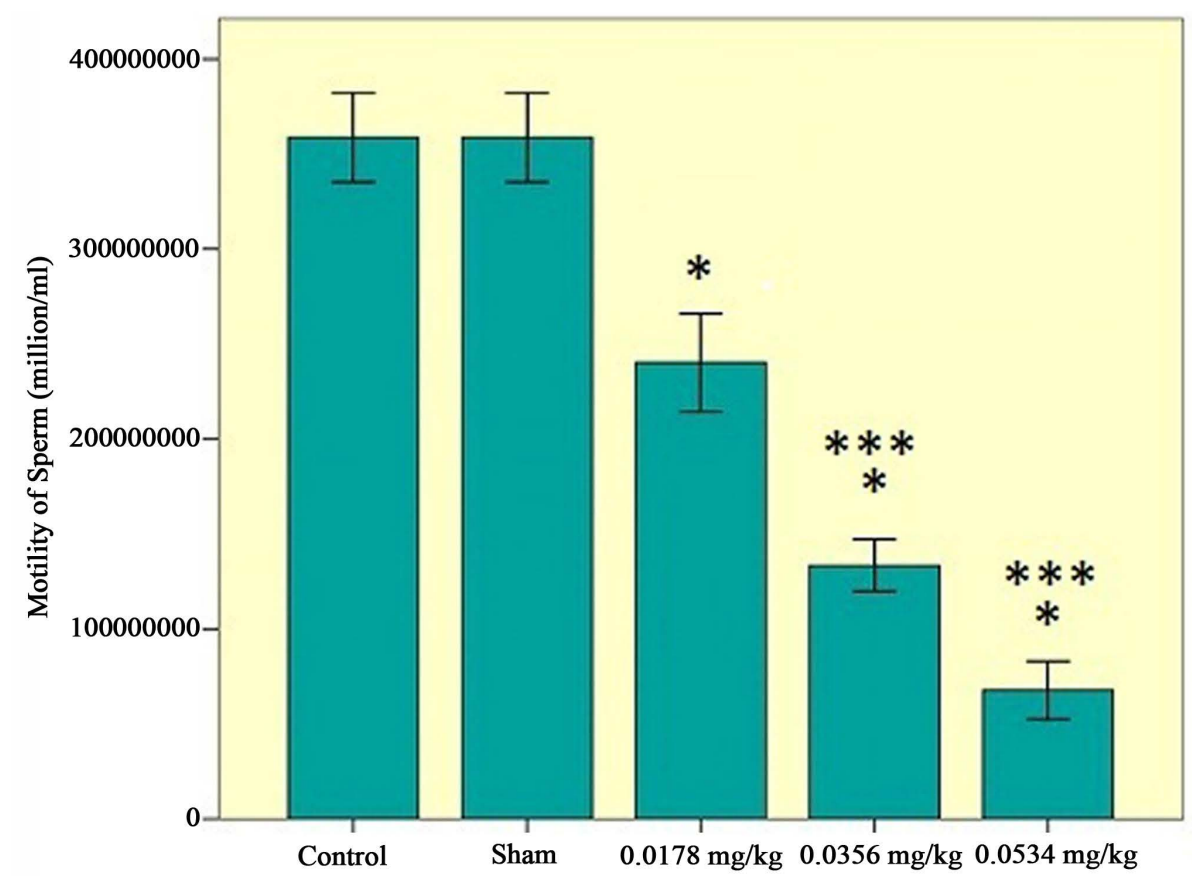

Figure 2. Number of sperms among the experimental groups $(0.0178 \mathrm{mg} / \mathrm{kg}, 0.0356 \mathrm{mg} / \mathrm{kg}$, $0.0534 \mathrm{mg} / \mathrm{kg}$ ), control and sham groups. Statistical analysis (Tukey test) was performed on the $\bar{X} \pm$ S.E.M of the absolute values, ${ }^{*} \mathrm{P} \leq 0.05$ and ${ }^{* * *} \mathrm{P} \leq 0.001$ for experimental, control and sham groups. 


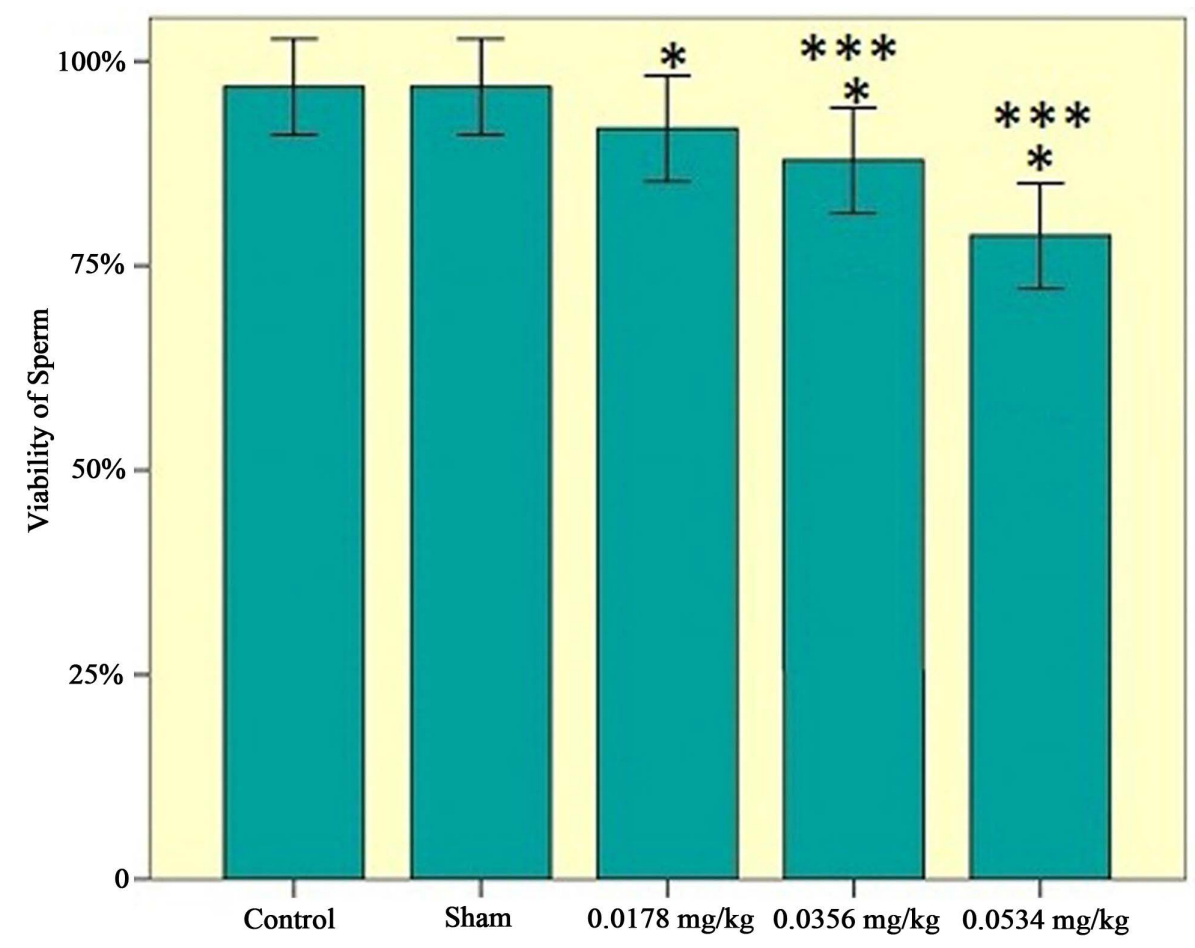

Figure 3. Viability of sperms among the experimental groups $(0.0178 \mathrm{mg} / \mathrm{kg}, 0.0356 \mathrm{mg} / \mathrm{kg}$, $0.0534 \mathrm{mg} / \mathrm{kg}$ ), control and sham groups. Statistical analysis (Tukey test) was performed on the $\bar{X} \pm$ S.E.M of the absolute values, ${ }^{*} \mathrm{P} \leq 0.05$ and ${ }^{* * *} \mathrm{P} \leq 0.001$ for experimental, control and sham groups.

(Figure 2).

c) Effects of sertraline on sperm viability: There is a significant decrease in viability of sperms. Using three doses of sertraline $(0.0534 \mathrm{mg} / \mathrm{kg})$ has the most influence on decreasing the viability of sperm (Figure 3).

\subsection{Hormone Levels}

Mean serum concentration of testosterone, FSH and LH levels of blood are presented in the Figures 4-6, respectively.

a) Effects of sertraline on testosterone level of blood: There is a significant decrease in testosterone level of blood. Using three doses of sertraline $(0.0534 \mathrm{mg} / \mathrm{kg})$ has the most influence on decreasing the testosterone level of blood (Figure 4).

b) Effects of sertraline on FSH level of blood: There was a significant increase in FSH level of blood. Using three doses of sertraline has the most effect on increasing the FSH level of blood (Figure 5).

c) Effects of sertraline on LH level of blood: There is no significant difference in LH level of blood among the experimental groups, sham and control groups (Figure 6).

\section{Discussion}

In this study, we investigated the effects of sertraline on sperm motility, number and viability, and Testosterone, FSH and LH levels of serum in adult male Balb/C mice. The motility, number and viability of sperms were decreased. FSH level of blood increased and this could be the reason for decreasing the number of sperms in adult male Balb/C mice.

It is well-know that spermatogenesis is the process of germ cell proliferation and differentiation within the seminiferous tubules of the testes leading to haploid, free spermatozoon. In fact, spermatogenesis requires complex endocrine [5] and auto/paracrine regulation as well as direct cell to cell interactions [6]. General features of neuroendocrine regulation of the testes by the hypothalamus and pituitary are well established. In response to 


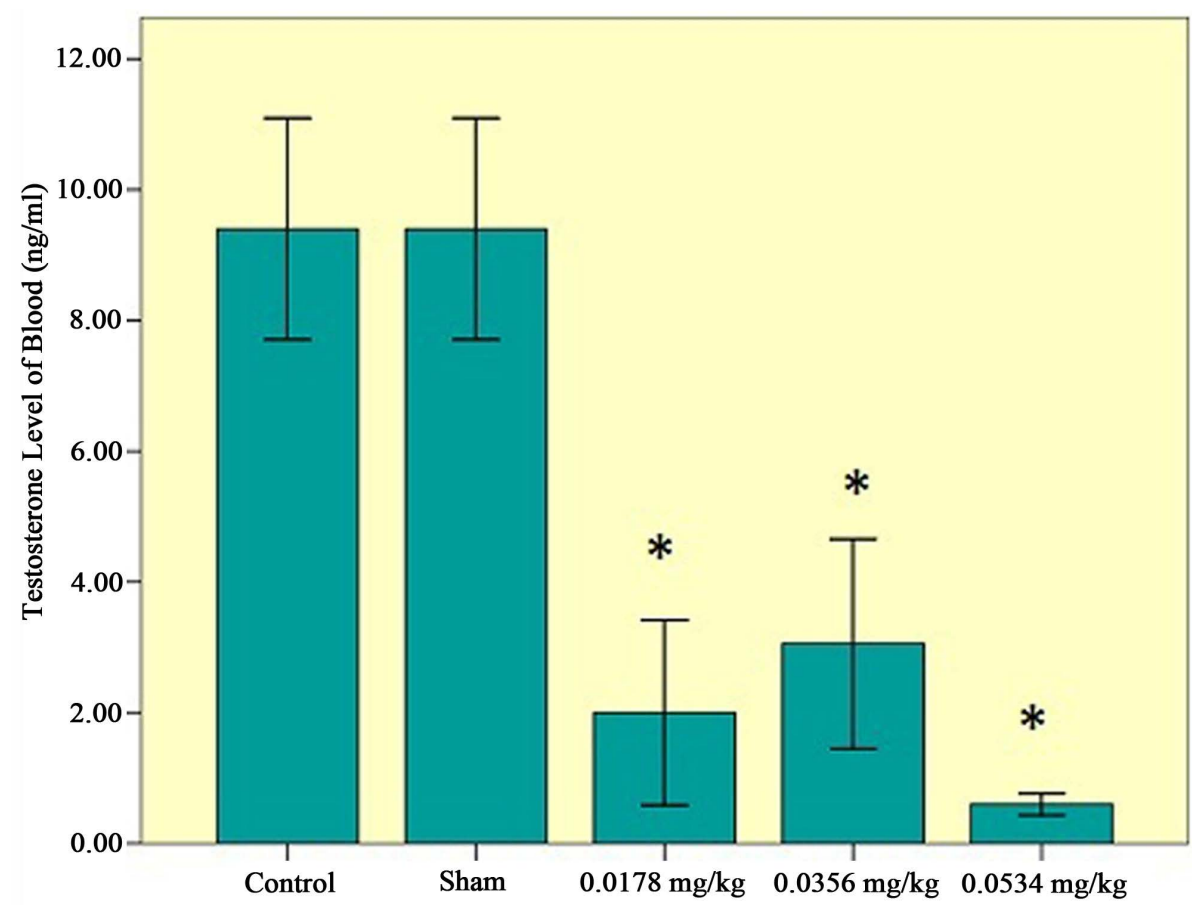

Figure 4. Testosterone hormone level of serum among the experimental groups $(0.0178 \mathrm{mg} / \mathrm{kg}$, $0.0356 \mathrm{mg} / \mathrm{kg}, 0.0534 \mathrm{mg} / \mathrm{kg}$ ), control and sham groups. Statistical analysis (Tukey test) was performed on the $\bar{X} \pm$ S.E.M of the absolute values, ${ }^{*} \mathrm{P} \leq 0.05$ and ${ }^{* * *} \mathrm{P} \leq 0.001$ for experimental, control and sham groups.

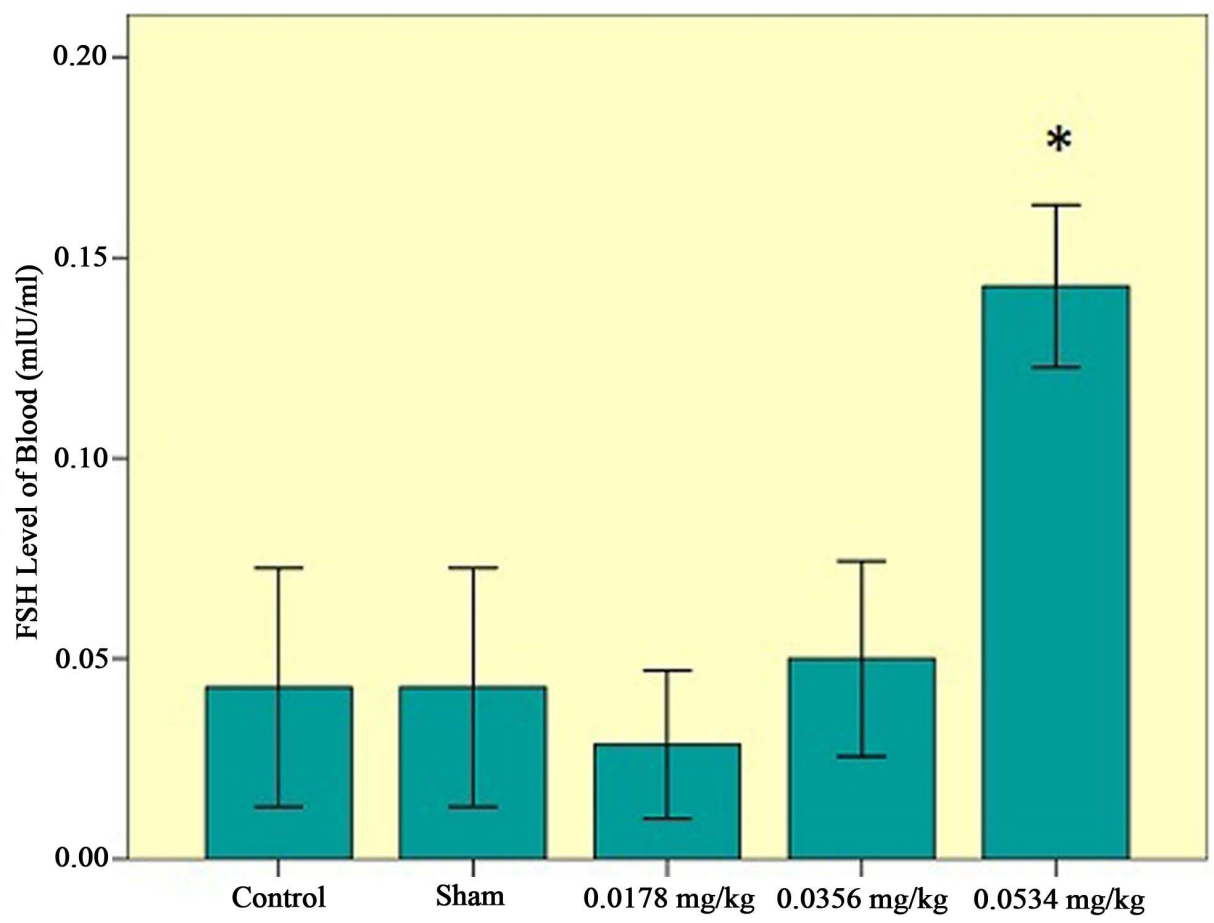

Figure 5. FSH level of serum among the experimental groups $(0.0178 \mathrm{mg} / \mathrm{kg}, 0.0356 \mathrm{mg} / \mathrm{kg}$, $0.0534 \mathrm{mg} / \mathrm{kg}$ ), control and sham groups. Statistical analysis (Tukey test) was performed on the $\bar{X} \pm$ S.E.M of the absolute values, ${ }^{*} \mathrm{P} \leq 0.05$ and ${ }^{* * *} \mathrm{P} \leq 0.001$ for experimental, control and sham groups. 


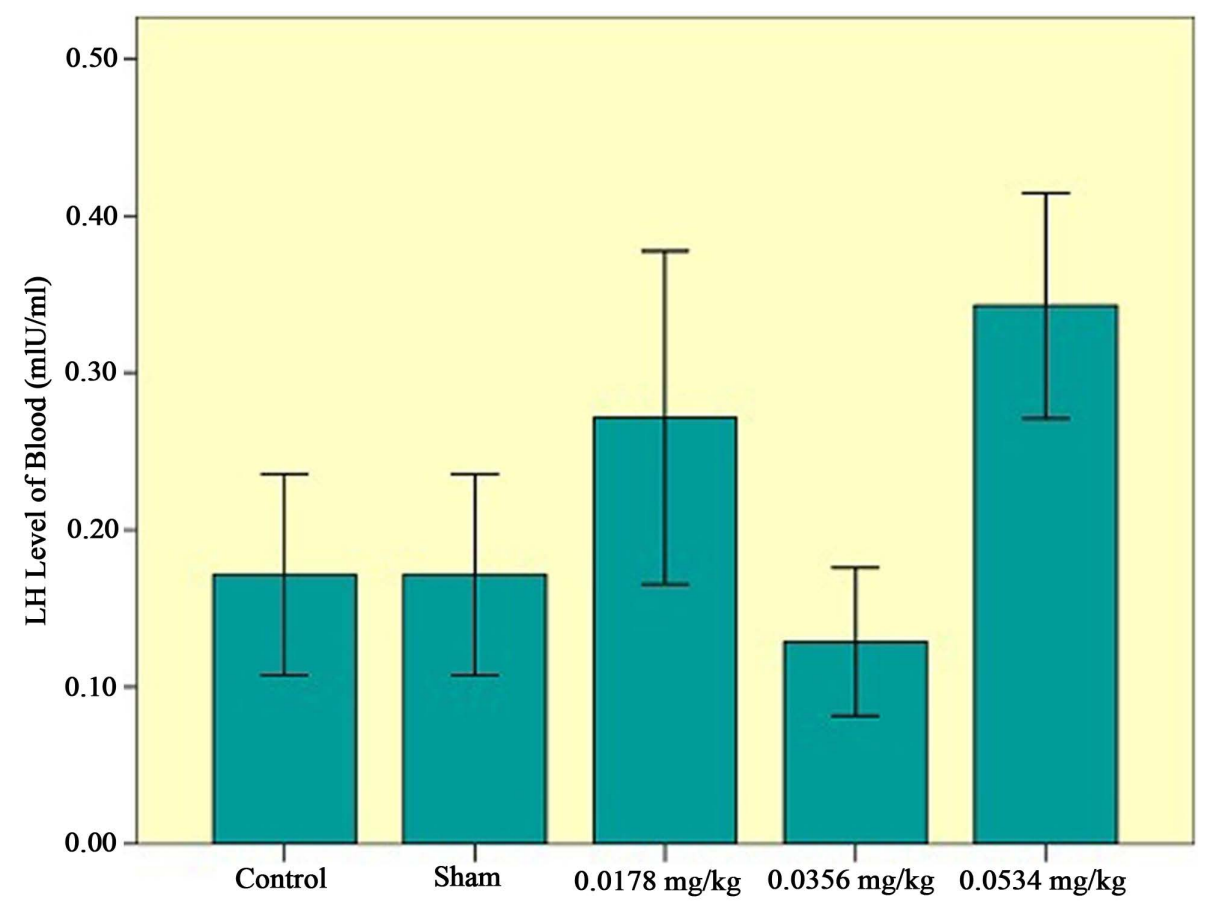

Figure 6. LH level of serum among the experimental groups $(0.0178 \mathrm{mg} / \mathrm{kg}, 0.0356 \mathrm{mg} / \mathrm{kg}$, $0.0534 \mathrm{mg} / \mathrm{kg}$ ), control and sham groups. Statistical analysis (Tukey test) was performed on the $\bar{X} \pm$ S.E.M of the absolute values, ${ }^{*} \mathrm{P} \leq 0.05$ and ${ }^{* * *} \mathrm{P} \leq 0.001$ for experimental, control and sham groups.

GnRH from the hypothalamus, the gonadotropins LH and FSH are produced and released from the anterior pituitary [11].

Spermatogenesis is affected by the pituitary hormone follicle stimulation hormone (FSH) and the male sex hormone testosterone produced by Leydig cells in the interstitial with the FSH receptors and the androgen receptor being restricted, to Sertli cells in the seminiferous epithelium [7]-[10]. The Sertoli cells in the seminiferous epithelium are targets for both FSH and testosterone [8] [10]. Seminiferous epithelium is capable of producing esterogenes from testosterone to regulate spermatogenesis [11]-[13].

Hormones such as testosterone, FSH and LH are known to influence the germ cell fate [14]. In human seminiferous tubules, apoptosis indicates under serum free conditions in vitro [15]. The fact that this apoptosis is suppressed by testosterone indicates that testosterone in the human male is a critical germ cell survival factor [12]. A consequence of decrease in intratesicular testosterone is that round spermatids lose their adhesion to the Sertoli cells, slough into the lumen of seminiferous tubules and are occasionally phagocytized by Sertoli cells [16] [17].

There is strong relationship between the Sertoli cell number and daily sperm production from spermatogonia [18]. In both human and horse, the number of Sertoli cells is related to the levels of spermatogenesis as measured as daily sperm production per testis [19].

It is generally known and frequently reported that FSH treatment would induce Sertoli cell proliferation in adult males [20]. Consequently, FSH increased the number of the earliest germinal cell generations and increased the differentiation of spermatogonia into spermatocytes [21].

In this research, we investigated that the Testosterone level of blood decreased while the FSH level of blood increased. Three doses of sertraline $(0.0534 \mathrm{mg} / \mathrm{kg})$ have the most effect on decreasing testosterone level of blood. On the other hand, it has the most effects on increasing FSH level of blood.

The effects of sertraline, a widely used antidepressant drug, on reproductive function are still under shadow. Searching thoroughly, no evidence exist upon normal low dose, that usually prescribe, however, some reports mention that it might decrease the testosterone level like other antidepressant drugs such as fluvoxamine, in higher amount. It can be assumed that high doses of sertraline, as a potent selective serotonin reuptake inhibitor, 
restrains the activity of enzyme engaged in steroid production path way of the testes tissue and leads to decrease the testosterone level of blood [22]. LH level of blood has no significant difference in using sertraline like fluvoxamine, citalopram and paroxitine [23]. Therefore, effects of sertraline on pituitary-gonad cycle in males may manifest as decrease on steroid production and male's sexual dysfunction.

\section{Conclusion}

The effects of sertraline on quantification of sperm and pituitary-gonad cycle were investigated in adult male mice. Our research indicates that sertraline especially at higher doses affects regulation of spermatogenesis: Decreasing the motility, number and viability of sperm causes the decrease of the quantification of sperm production and has the potential to affect adversely male fertility in mice. Furthermore, using sertraline at high doses may cause increment in the FSH level of blood. Increasing the FSH stimulates testosterone to release from Leydig cells. Also, decreasing testosterone level of blood, a hormone which is necessary to sperm production, leads to decrease in the motility, number and viability of sperm. It is assumed that decrease in intratesticular testosterone may cause round spermatids to lose their adhesion to the Sertoli cells, slough into the lumen of seminiferous tubules and consequently the number of sperm may decreases.

\section{References}

[1] Montgomery, S.A., Schatzberg, A.F., Guelfi, J.D., Kasper, S., Nemeroff, C., Swann, A., et al. (2000) Pharmacotherapy of Depression and Mixed States in Bipolar Disorder. Journal of Affective Disorders, 59, 39-56. http://dx.doi.org/10.1016/S0165-0327(00)00178-6

[2] Nemeroff, C.B. (1994) Evolutionary Trends in the Pharmacotherapeutic Management of Depression. Journal of Clinical Psychiatry, 55, 3-15.

[3] Montgomery, S.A. and Kasper, S. (1995) Comparison of Compliance between Serotonin Reuptake Inhibitors and Tricyclic Antidepressants: A Meta-Analysis. International Clinical Psychopharmacology, 9, 33-40. http://dx.doi.org/10.1097/00004850-199501004-00005

[4] Montgomery, S.A. (1996) Efficacy in Long-Term Treatment of Depression. Journal of Clinical Psychiatry, 57, 24-30.

[5] Zirkin, B.R. (1998) Spermatogenesis: Its Regulation by Testosterone and FSH. Seminars in Cell \& Developmental Biology, 9, 412-422. http://dx.doi.org/10.1006/scdb.1998.0253

[6] Mc Lachlan, R.I., D’Donnell, L., Meachem, S.J., Stanton, P.G., de Krester, D.M., Parti, S.K., et al. (2002) Identification of Specific Sites of Hormonal Regulation in Spermatogenesis in Rats, Monkeys, and Man. Recent Progress in Hormone Research, 57, 149-179. http://dx.doi.org/10.1210/rp.57.1.149

[7] Kretser, D. and Kerr, J. (1988) The Cytology of the Testis. In: Knobil, E., et al., Eds., The Physiology of Reproduction, Raven Press, New York, 837-932.

[8] Sharpe, R.M. (1988) Regulation of Spermatogenesis. In: Knobil, E. and Neill, J.D., Eds., The Physiology of Reproduction, Raven Press, New York, 1363-1434.

[9] Mruk, D. and Cheng, C.Y. (2004) Sertoli-Sertoli and Sertoli-Germ Cell Interactions and Their Significance in Germ Cell Movement in the Seminiferous Epithelium during Spermatogenesis. Endocrine, 25, 747-806.

[10] Walker, W.H. (2009) Molecular Mechanisms of Testosterone Action in Spermatogenesis. Steroids, 74, 602-607. http://dx.doi.org/10.1016/j.steroids.2008.11.017

[11] Shaha, C. (2008) Estrogens and Spermatogenesis. In: Cheng, C.Y., Ed., Molecular Mechanisms in Spermatogenesis, Landes Bioscience and Springer Science Business Media, Austin, 42-64.

[12] Sofikitis, N., Giotitsas, N., Tsounapi, P., Baltogiannis, D., Giannakis, D. and Pardalidis N. (2008) Hormonal Regulation of Spermatogenesis and Spermiogenesis. Journal of Steroid Biochemistry \& Molecular Biology, 109, 323-330. http://dx.doi.org/10.1016/j.jsbmb.2008.03.004

[13] Cheng, C.Y., Wong, E.W.P., Yan, H.H.N. and Mruk, D. (2010) Regulation of Spermatogenesis in the Microenvironment of the Seminiferous Epithelium: New Insights and Advances. Molecular and Cellular Endocrinology, 315, 49-56. http://dx.doi.org/10.1016/j.mce.2009.08.004

[14] Pentikainen, V., Erkkila, K., Suomalainen, L., Parvinen, M. and Dunkel, L. (2000) Estra-Diol Acts as a Germ Cell Survival Factor in the Human Testis in Vitro. Journal of Clinical Endocrinological Metabolism, 85, 2057-2067.

[15] Erkkila, K., Henriksen, K., Hirvonen, V., Rannikko, S., Salo, J., Parvinen, M. and Dunkel, L. (1997) Testosterone Regulates Apoptosis in Adult Human Seminiferous Tubules in Vitro. Journal of Clinical Endocrinological Metabolism, 82, 2314-2321. 
[16] Show, M.D., Folmer, J.S., Anway, M.D. and Zirkin, B.R. (2004) Testicular Expression and Distribution of the Rat Bcl-2 Modifying Factor (Bmf) in Response to Reduced Intratesticular Testosterone. Reproductive Biology, 70, 11531161. http://dx.doi.org/10.1095/biolreprod.103.023200

[17] Parks, J.E., Lee, D.R., Huang, S. and Kaproth, M.T. (2003) Prospects for Spermatogenesis in Vitro. Theriogenology, 59, 73-86. http://dx.doi.org/10.1016/S0093-691X(02)01275-X

[18] Johnson, L., Thompson, J.D.L. and Varner, D.D. (2008) Role of Sertoli Cell Number and Function on Regulation of Spermatogenesis. Animal Reproduction Science, 105, 23-51. http://dx.doi.org/10.1016/j.anireprosci.2007.11.029

[19] Johnson, L. and Nguyen, H.B. (1986) Annual Cycle of the Sertoli Cell Population in Adult Stallions. Journal of Reproductive Fertility, 76, 311-316. http://dx.doi.org/10.1530/jrf.0.0760311

[20] Orth, J.M., Gunsalus, G.L. and Lamperti, A.A. (1988) Evidence from Sertoli Cell-Depleted Rats Indicates That Spermatid Number in Adults Depends on Numbers of Sertoli Cells Produced during Perinatal Development. Endocrinology, 122, 787-794. http://dx.doi.org/10.1210/endo-122-3-787

[21] Tarulli, G.A., Stanton, P.G., Lerchl, A. and Meachem, S.J. (2006) Adult Sertoli Cells Are Not Terminally Differentiated in the Djungarian Hamster: Effect of FSH on Proliferation and Junction Protein Organization. Biological Reproduction, 74, 798-806. http://dx.doi.org/10.1095/biolreprod.105.050450

[22] Hedger, M.P., Khtab, S., Gonzales, G. and de Krester, D.M. (1995) Acute and Short-Term Actions of Serotonin Administration on the Pituitary-Testicular Axis in the Adult Rat. Reproductive Fertile Development, 7, 1101-1109. http://dx.doi.org/10.1071/RD9951101

[23] Ferrero, A.J., Ceresseto, M., Reines, A., Bonavita, C.D., Sifonios, L.L., Rubio, M.C., et al. (2005) Chronic Treatment with Fluoxetine Decreases Seizure Threshold in Naïve but Not in Rats Exposed to the Learned Helplessness Paradigm; Correlation with the Hippocampal Glutamate Release. Neurepsy Chopharmacol Biopsychiatry, 29, 678-686. 